\title{
Student entrepreneurship - research on development
}

\author{
Matgorzata Rembiasz ${ }^{1, *}$ \\ ${ }^{1}$ Poznań University of Technology, Faculty of Engineering Management, Strzelecka 11, Poznań, \\ Poland
}

\begin{abstract}
The article discusses selected theoretical aspects of student entrepreneurship and the findings of the author's research in this field. Academic entrepreneurship programmes constitute a significant component of higher education. In the empirical part of the study, which relied on auditorium surveys, the author found that students are strongly motivated to engage in business pursuits and identified barriers to their entrepreneurial engagement. The respondents varied widely in their opinions on the nature of entrepreneurship and enterprises. Such a broad range of opinions underscores the complexity of entrepreneurship in today's economies. Programmes of entrepreneurship education in higher education systems should place greater emphasis on the formalities required for starting a business and raising funds for this purpose. The development of entrepreneurial skills from a young age should be recognised as critical for creating a community capable of functioning in a knowledge-based economy.
\end{abstract}

\section{Introduction}

In the classical view represented by P. Drucker, entrepreneurship is seen as a specific approach to management, which involves "adopting innovations that constitute the basis of future business" while "making the best possible use of the available resources" [1].This suggests a strong link between innovation and entrepreneurship. The existence of the link was posited earlier by J. Schumpeter who proposed that one only becomes an entrepreneur provided one engages in innovation and that one stops being one as soon as one settles into an entrenched market position and routine ways of operating one's business. Furthermore, according to Schumpeter, entrepreneurship is a driver of all rapid changes in economies [2].

A contemporary approach consistent with the definition proposed by the Global Entrepreneurship Monitor views entrepreneurship as "any attempt at new business or new venture creation, such as self-employment, a new business organisation, or the expansion of an existing business, by an individual, a team of individuals, or an established business" [3].

The term entrepreneurship has multiple meanings. Due to this variety, both the theoretical and practical aspects of entrepreneurship provide fertile ground for the

\footnotetext{
* Corresponding author: malgorzata.rembiasz@put.poznan.pl
} 
development of research in a wide range of fields, predominantly management, economics, sociology, psychology and education. Hence, entrepreneurship literature also abounds with interdisciplinary publications. As a consequence, a number of definitions and classifications of entrepreneurship have been proposed ranging from simple to highly complex [4].

The central role of education in this context across nearly all fields and levels is not only to offer knowledge that matches the needs of existing businesses but also to encourage and prepare students to be open to self-employment and job creation. The article presents selected theoretical aspects of student entrepreneurship along with findings of own research in the field carried out in two Poznań institutions of higher learning.

\section{Academic entrepreneurship - selected theoretical aspects}

\subsection{Academic entrepreneurship as a driver of growth of national economies}

Entrepreneurship propels the growth of Poland's economy in a number of ways. Small and medium-sized enterprises exert a significant impact on numerous macroeconomic parameters. SMEs account for a growing share of international trade and for $65-70 \%$ of the total employment in business organisations across Poland and many other countries [3].

The performance of SMEs also reflects engagement in business and contributes to the rise of the middle class in society at large.

Against the background of Poland's overall economic growth, the advancement of the country's small and medium-sized enterprises is contingent upon the successful adoption of various forms of innovation on a larger scale [5].

Defined broadly as the integration of science and business, student entrepreneurship may take any of a number of various forms, the most prominent of which being educational cooperation, business counselling, the organisation of joint research programmes and the creation of enterprises by researchers and, above all, by university students and graduates. Academic entrepreneurship relies chiefly on the creativity of student communities and the extent to which their outcomes are applied in business practice. Efficient cooperation between the academic and economic sectors should be a cornerstone of the national economic policy [6].

A major role in the economic development of any country is played by family firms. This is because the values cultivated by generations of family entrepreneurs tend to inspire young people and family business successors [7]. Note also the strong link that exists between family and student entrepreneurship. As demonstrated by K. Wach by means of empirical research, the family business exposure has the effect of encouraging students to engage in entrepreneurial activities. Such exposure drives the young generation to embrace entrepreneurial values and appreciate the prominent role of entrepreneurs in society. As a consequence, young people show a greater propensity to taking business risks [8].

Note also that the entrepreneurial spirit can be instilled in young people even in childhood. As the bulk of child rearing and education in Poland and many other countries is in the hands of mothers and grandmothers, it is essential for the state to support women's entrepreneurship across all age brackets and family backgrounds [9]. This applies in particular to single mothers. Since more than $20 \%$ of children in Poland are raised by single parents, it is crucial to enable single mothers to contribute actively to the social and economic growth of the country also by starting and running their own businesses. This will enable them to become entrepreneurial role models for their children [10]. Instilling entrepreneurial attitudes from an early age should be recognised as a critical part of child development and, consequently, as a prerequisite for creating a society capable of operating successfully in modern knowledge-based economies. 
Just as any form of engagement in business, student entrepreneurship ties closely to the political and public approval for self-employment. It appears that not enough attention is paid to the role of entrepreneurship in today's market economy, including that of Poland, the role of small and medium-sized businesses in national economies, entrepreneurship education, the popularization of self-employment as a viable career option and the encouragement of self-employment. To remedy these shortcomings, academia need to work closely together with business practitioners [6].

\subsection{Higher entrepreneurship education - selected theoretical considerations}

Entrepreneurship ranks among the so-called key competences in the European educational system. The idea of including entrepreneurship education at every level of learning holds a prominent place in European Union policies, especially since the start of the $21^{\text {st }}$ century [11]. Entrepreneurship education is a priority in the EU's education policy. The Bruges Communiqué on enhanced European Cooperation in Vocational Education and Training for the period 2011-2020 called upon the participating countries to "support newly-established and future entrepreneurs by encouraging start-ups for VET graduates and by promoting learning mobility for young entrepreneurs" [12].

A particular role in encouraging student entrepreneurship should be played by education in the use of modern IT tools in business. For instance, companies are increasingly promoted not only with their own websites but also through a range of social media $[13,14]$.

According to Okoń-Horodyńska, education today should rely primarily on teaching students to act independently, self-organise quickly and adapt their business to changing micro- and macroeconomic environments. In the process of education, pro-entrepreneurial behaviours should be strengthened by providing multidimensional knowledge in economics, psychology, cultural sociology, anthropology, information technology, social communications and law [15].

\section{Student entrepreneurship - empirical research findings}

\subsection{Description of survey}

In January 2017, a survey was conducted of the students of three institutions of higher education: the Poznań University of Technology (students majoring in Technical/IT Education), the WSB of Poznań (students majoring in Business Law, Logistics and Tourism and Recreation) and the State School of Higher Vocational Education in Leszno (students majoring in Economics). The study sample comprised of the students of economics programmes as well as those of technical studies leading to engineering degrees.

The study relied on quantitative methods and specifically the auditorium survey. The survey form was completed by a total of 166 respondents. The majority of them $(68 \%)$ were women. $89 \%$ belonged to the $18-25$ age group. $42 \%$ of the respondents resided in rural areas, $19 \%$ were large city dwellers while the remaining participants indicated they had come from smaller towns (with populations of less than 200,000). The majority of the respondents $(57 \%)$ were enrolled in the second year, another $31 \%$ in the first year while the remaining ones attended the third, fourth and fifth years of their programmes. Only $10 \%$ of the surveyed had already completed a higher education programme, meaning they were pursuing a second degree. 


\subsection{Attitudes towards entrepreneurship by surveyed students}

Attitudes towards entrepreneurship correlated closely with the respondents' intent to set up a business. The results are shown in Table 1.

Table 1. Respondent declarations of intent to start and run own business

\begin{tabular}{|l|c|}
\hline Current employment and plans for the future & $\begin{array}{c}\text { Percentage of } \\
\text { responses } \\
{[\%]}\end{array}$ \\
\hline I operate my own business of which I am either an owner or co-owner & 7.2 \\
\hline I am employed but want to start my own business & 10.2 \\
\hline I am not employed but want to start my own business & 21.7 \\
\hline I am employed and do not know if I want to start my own business & 22.3 \\
\hline I am not employed and do not know if I want to start my own business & 28.3 \\
\hline I am employed and do not want to start my own business & 3.6 \\
\hline I am not employed and do not want to start my own business & 6.6 \\
\hline
\end{tabular}

Source: own research

The above summary of responses shows that $39.1 \%$ of the respondents displayed an active entrepreneurial mind-set: $31.9 \%$ planned to start their own business while $7.2 \%$ already owned one. Meanwhile, only $10.2 \%$ of the students indicated having no entrepreneurial intent. The largest group (of 50.6\%) were the undecideds, who were unable to define their intents concerning their future self-employment.

A significant aspects of the research on the respondents' attitudes towards entrepreneurship was their self-perception as enterprising people. However, a survey held in 2010 and repeated in 2016 in the institutions of higher education in the Polish region of Wielkopolska showed that a person's self-perception as being an enterprising individual did correlated poorly with plans to set up one's own firm. The 2016 phase of the study demonstrated that students tended to view themselves as enterprising. Such a selfperception was indicated by $68.8 \%$ of female and $59 \%$ of male first-year students as well as $64.9 \%$ female and $70 \%$ of male third-year students. However, only a certain proportion of such respondents were prepared to use such confidence to actually start a business. Studies have found that $50.1 \%$ of female and $38.5 \%$ of male first-year students as well as $37.9 \%$ of female and $47 \%$ of male third-year students intended to start up their own company in either near or more remote future. Note that a comparison of the 2010 and 2016 findings shows that although the respondents to the 2016 study thought of themselves as being more enterprising, the number of students planning to go into business for themselves declined whereas the number of undecideds and those determined not to engage in a business venture went up [4].

Note also the findings of a study comparing the attitudes towards entrepreneurship displayed by the students of programmes in economics, social studies and the humanities. The study found that the majority of the students consider themselves to be enterprising, which they understand as being able to take risks, be ingenious and creative and show initiative. However, some $40 \%$ of the student sample did not, during their studies, holds jobs associated with their majors. According to the authors, the main barriers to such engagement were the students' reluctance to build their careers shortly after enrolment with their universities and lacking a business idea for starting and operating their enterprise [16].

One other factor of possible significance in this context is the way entrepreneurship is viewed by students. The above-mentioned 2016 study requested that students define the notion of "entrepreneurship". The respondents offered a wide range of interpretations. Some perceived entrepreneurship mainly as running one's own business and generating an income. Others focused on the other meaning of the Polish equivalent of the term focused 
on "enterprise and resourcefulness". Such students saw entrepreneurship as a set of personality traits. All in all, the study provided further evidence for the great complexity of entrepreneurship in today's economy [4].

\subsection{Barriers to the advancement of student entrepreneurship}

Factors for the advancement of student entrepreneurship should be identified against the background of barriers to entrepreneurship found in the economy. Literature frequently refers to the main five categories of barriers identified by the Polish Agency for Enterprise Development, which are legal, economic, managerial, educational and social.

In the study in question, the respondents were requested to select what they believed were the top three factors that tend to frustrate the intents to start and run a business. Their opinions are summarised in Table 2.

Table 2. Key barriers to starting and operating own business

\begin{tabular}{|l|c|}
\hline $\begin{array}{l}\text { Factors hampering the development of } \\
\text { entrepreneurship }\end{array}$ & $\begin{array}{c}\text { Percentage of responses } \\
{[\%]}\end{array}$ \\
\hline Tax system & 59.6 \\
\hline Difficulties with securing funding & 59.6 \\
\hline Absence of a "good business idea" & 54.2 \\
\hline Little time left for personal life & 30.7 \\
\hline $\begin{array}{l}\text { No knowledge on how to operate a } \\
\text { business }\end{array}$ & 42.8 \\
\hline No support from economic policies & 34.9 \\
\hline No support from family & 4.2 \\
\hline
\end{tabular}

Source: own research

According to the respondents, the key barriers to starting and running one's own business in Poland were the tax system and difficulties with securing funds. The very same barriers have been identified in a variety of reports published by the Polish Agency for Enterprise Development and in a number of scientific studies. Small and medium-sized business owners frequently point to difficulties accessing third party capital as a major inhibitor of entrepreneurship. Precisely this conclusion has been proposed by T. Łuczka $[17,18]$. Note that the research described in this article suggests that only a mere $27 \%$ of the respondents searched the Internet for ways to finance a business venture over the preceding year.

Note also that $42.8 \%$ of the respondents pointed to the lack of knowledge on how to operate a business as one of the top three obstacles. This particular barrier can be dismantled by offering entrepreneurship education at all levels of schooling, particularly in higher learning.

A study by K. Dąbrowska and M. Skowron found that young people rarely notice good opportunities for starting a business in their environments. Therefore, one of the main responsibilities of institutions of higher education should be to promote entrepreneurship by encouraging young people to take advantage of the opportunities by starting their own businesses. To make that possible, it is vital that an entrepreneurship-friendly atmosphere be created in the market environment not only at the regional but also the local level, thereby strengthening the resolve of potential entrepreneurs [16].

\subsection{Student motivations to start/run a business}

A number of systems are available for classifying drivers for the establishment and advancement of entrepreneurship, including student entrepreneurship. One of them, 
designed by D. Piróg, resulted from an overview of multiple perspectives on the issue. Piróg's classification refers to both external factors: (1) basic macroeconomic indicators, and (2) social influences - the social capital, as well as external variables: (3) competences and qualifications - education and experience, and (4) the personal traits of individuals [19].

Research conducted by the students of the Pedagogical University of Kraków has identified a plethora of factors that affect young people's entrepreneurial intent. In keeping with planned behaviour theory, some of the most important of them are views on private enterprise, the propensity to take risks, subjective public perceptions of private enterprise, the self-perceived effectiveness in business ventures and early exposure to business within one's family [20].

The participants in the research carried out by the article's author pointed not only to barriers to but also to factors that foster the starting and running of one's own enterprise (they were asked to select the top three factors). The students' choices of the three most influential drivers of student entrepreneurship are provided in Table 3.

Table 3. Key incentives to start and run a business

\begin{tabular}{|l|c|}
\hline Entrepreneurship driver & $\begin{array}{c}\text { Percentage of } \\
\text { responses [\%] }\end{array}$ \\
\hline Opportunity to earn higher income & 73.5 \\
\hline Opportunity to pursue one's passions & 65.7 \\
\hline Independence ("no boss") & 60.8 \\
\hline Opportunity to balance work and personal life & 39.2 \\
\hline Necessity (no jobs available) & 4.8 \\
\hline Access to state support available under economic policies & 4.2 \\
\hline
\end{tabular}

Source: own research

The bulk of research on entrepreneurship points to the opportunity to earn a higher income as the top driver of entrepreneurship. The income factor was also the incentive most frequently selected by the student respondents to this study. The second most commonly chosen factor behind business start-up was the chance to pursue one's passion, the third: independence. Such findings are consistent with the overall profile of the so called generation $\mathrm{Z}$, which is currently entering the labour market and to which the majority of the respondents belong. This demographic cohort is highly mobile, individually-minded, creative and valuing self-improvement and independence. Note also that a substantial proportion of the respondents $(39.2 \%)$ selected the opportunity to balance one's work and personal life. This emphasis can be associated with the fact that the study sample was comprised of predominantly female respondents. For the sake of comparison, an impressive $30.7 \%$ chose limited time for personal life as a factor discouraging them from starting a business.

As noted earlier, students' attitudes towards entrepreneurship are largely affected by their social backgrounds, including exposure to enterprise pursued by either their family members and close friends. The study conducted for the purposes of this publication showed that $24 \%$ of the respondents did not know closely anyone who ran their own company. $45 \%$ of the students came from families whose close members (parents, grandparents, siblings, aunts or uncles) owned their own businesses whereas $31 \%$ indicated that an extended family member or a close friend was a business proprietor. The conclusion therefore is that exposure to the business experience in one's family had little effect on encouraging students to set up their own ventures. Perhaps being witness to the hard work and constant strife against many odds (including a rather unfriendly tax system) as well as the recent decline in unemployment in Poland discourages young people from engaging in their own business pursuits. 


\section{Conclusions}

Enterprise ranks among the key factors for improving the competitiveness of businesses and promoting the social and economic development of countries. Whereas student entrepreneurship, as examined in terms of selected aspects, appears to be a highly complex issue, its advancement can certainly be ensured by promoting self-reliance and encouraging entrepreneurial intent, mainly in universities. Today's free-market economy clearly requires an entrepreneurial spirit and managerial skills on the part of graduates in nearly every field, not just economics and business management.

Particular importance can be ascribed to, on the one hand, the incorporation into university curricula of legal, economic and institutional aspects of entrepreneurship, the commercialization of science and technology and intellectual property rights and, on the other, collaboration between institutions of education and business practitioners, particularly enterprises and their inclusion in teaching practice, as well as the development of entrepreneurship infrastructure institutions and programmes (Poznańska 2014).

Research has shown that nearly $40 \%$ of the surveyed students demonstrate an active entrepreneurial mind-set while only $10 \%$ categorically rule out the option of running their own company. Entrepreneurship education should focus on reducing the number of the undecideds (who account for approximately $50 \%$ of the surveyed) who are unable to define their intent to start up their own business. Specifically, such education should focus on identifying the benefits of actively committing to a business venture and on providing knowledge that can be transformed into entrepreneurial competences and lead to starting a business. This is particularly critical in view of the fact that a staggering $43 \%$ of the respondents named the lack of business knowledge as one of the top three barriers to starting and running an enterprise. Furthermore, according to the respondents, the prime reasons for choosing to start one's own business are opportunities to earn a higher income and pursue one's passions as well as independence. Such an outcome stems from the fact that the majority of the respondents belonged to the so-called generation $\mathrm{Z}$, which is characterised by great self-reliance, creativity and emphasis on self-improvement.

Note that according to J. Wasilczuk, who is an experienced researcher of entrepreneurship in Poland, one cannot escape subjectivism in either qualitative or quantitative research on entrepreneurship. By adopting a subjective view, scholars are likely to propose new research methods and new approaches. Subjectivism also tends to promote arbitrariness in research making it difficult to provide definitive answers to research questions. Two potential solutions to this problem are to consult research methodology design decisions within larger teams of researchers concerned with a specific area and to abandon large-scale studies on heterogeneous samples in favour of smallerscale projects using homogenous samples, which are better positioned to offer more profound insights [21].

The author realises that the discussion provided in her article is fairly general. She is therefore planning to conduct more research at a greater level of detail on student entrepreneurship and its drivers and, in particular, the needs of entrepreneurship education programmes seen as providing a fundamental social competence. Continued research in the field may help strengthen entrepreneurial attitudes among young Poles.

\section{References}

1. P. Drucker, Innovation and entrepreneurship. Practice and principles, (Heinemann, 1992)

2. J. Schumpeter, The Theory of Economic Development: An Inquiry into Profits, Capital, Credit, Interest and the Business Cycle, New Brunswick and London (2008)

3. Report on Global Entrepreneurship Monitor - Poland 2015, PARP (2016) 
4. T. Łuczka, M. Rembiasz, Horyzonty Wychowania, 15 (34), 27-47 (2016)

5. A. Borowiec, The Use of Electronic Tools in Public Procurement as a Factor Spurring Demand for Innovative Solutions in the Economy, according to Contractors, IMECS 2016, 418-431 (2016)

6. K., Poznańska, Przedsiębiorczość akademicka - cechy $i$ znaczenie $w$ gospodarce światowej $i$ polskiej. in: T. Kraśnicka (ed.), Innowacyjność wspótczesnych organizacji. Kierunki $i$ wyniki badań [II]. Katowice: UE, 164-172 (2014)

7. B. Roszkowska-Mądra, A. Parfieniuk, M. Studnicki, Studia Ekonomiczne 6 (72), 217-235 (2014)

8. K. Wach, L. Wojciechowski, EBER 4 (1), 83-94 (2016)

9. P. Siemieniak, T. Łuczka, Przedsiębiorczość kobiet. Wybrane aspekty ekonomiczne $i$ psychokulturowe, Poznan (2016)

10. M. Rembiasz, Zeszyty Naukowe Politechniki Poznańskiej. Organizacja i Zarządzanie 68, 167179 (2016)

11. K. Wach, Horyzonty Wychowania 13(26), 11-32 (2014)

12. http://ec.europa.eu/education/policy/vocational-policy/doc/brugescom_pl.pdf (as accessed on 15.01.2016)

13. J. Pawlak, P. Siemieniak, Zeszyty Naukowe Politechniki Poznańskiej. Organizacja i Zarządzanie 68, 179-190 (2016)

14. P. Siemieniak, M. Rembiasz, J. Pawlak, Internet as a tool to promote women's entrepreneurship. Selected aspects, Studia i Materiały (to be published)

15. E. Okoń-Horodyńska,. Nauka i Szkolnictwo Wyższe 1(31), 34-54 (2008)

16. K. Dąbrowska, M. Skowron, Annales. Etyka w życiu gospodarczym, 18 (3), 121-131, (2015)

17. T. Łuczka T., Makro- i mikroekonomiaczne determinanty struktury kapitalu w matych i średnich przedsiębiorstwach, Poznan (2013)

18. J. Małecka, T. Łuczka, The Structure of Venture Capital Raising by Companies in Poland and Central and Eastern Europe: Selected Aspects, IMECS 2016, 418-431 (2016)

19. D. Piróg,. Przedsiębiorczość - Edukacja 10, 306-315 (2014)

20. T. Rachwał, K. Wach., Przedsiębiorczość - Edukacja 12, 405-415 (2016)

21. J. Wasilczuk, Problemy Zarządzania 1 (51), 13-25 (2015) 